\title{
Assessment of the developmental status of 3 to 5-year-old children with congenital hypothyroidism treated with levothyroxine in Ardabil city
}

\author{
Mehrdad Mirzarahimi ${ }^{1}$, Afshan Sharghi ${ }^{2}$, Mohammad Zaman Zamanpour $^{1}$, Reza Maskani ${ }^{3}$
}

${ }^{1}$ MD, Department of Pediatrics, Faculty of Medicine, Ardabil University of Medical Sciences, Ardabil, Iran

${ }^{2}$ MD, Department of Community Medicine, Faculty of Medicine, Ardabil University of Medical Sciences, Ardabil, Iran

${ }^{3} \mathrm{MD}$, Faculty of Medicine, Ardabil University of Medical Sciences, Ardabil, Iran

\section{Type of article: Original}

\begin{abstract}
Background: Congenital hypothyroidism $(\mathrm{CH})$ is one of the most common preventative evolutionary disorders in newborns and children, which, if not treated promptly, leads to mental retardation and developmental disorders.

Objective: The purpose of this study was to assess the developmental status of 3 to 5 -year-old children with congenital hypothyroidism treated with levothyroxine in Ardabil city in Northwest Iran.

Methods: In a descriptive cross-sectional study, 78 infants (44 boys and 34 girls) with congenital hypothyroidism under treatment with levothyroxine who referred to Ardabil city health centers during 2013-2018 were evaluated by an Ages and Stages Questionnaire (ASQ) for their developmental status.

Results: In total, 32 (41\%) were impaired and $46(59 \%)$ were healthy according to the ASQ. Of those, 11 children $(14.1 \%)$ had temporary congenital hypothyroidism. There was no significant difference in terms of height, weight, birth weight, maternal age, number of tests performed each year, average TSH (Thyroidstimulating Hormone) in the first year of treatment, gender, place of residence, education and parental relationship between two impaired and healthy children. There was a significant relation between number of visits by doctor $(\mathrm{p}=0.02)$, age at diagnosis $(\mathrm{p}=0.001)$ and age at treatment time $(\mathrm{p}=0.003)$, initial dose of levothyroxine $(\mathrm{p}=0.02)$ with developmental status of children based on ASQ results.

Conclusion: According to the findings of this study, it can be concluded that neonatal screening is one of the most successful health-system programs in the country, and the detection and initiation of hypothyroidism in neonates as soon as possible leads to a reduction in developmental disorder in them.

Keywords: Children, Congenital Hypothyroidism, Development, Thyroid
\end{abstract}

Abbreviations / Acronyms:

ASQ: Ages and Stages Questionnaire; CH: Congenital hypothyroidism; WHO: World Health Organization

\section{Introduction}

Thyroid hormones are one of the most important hormones involved in the development of the human nervous system $(1,2)$. Congenital hypothyroidism $(\mathrm{CH})$ is one of the most common congenital endocrine abnormalities due to thyroid hormone deficiency and it is seen in both transient and constant forms. It is one of the most common causes of preventable mental retardation in children and its prevalence in some countries is one in every three to four thousand live births $(3,4)$. Removal of iodine from the bloodstream is the first essential step in the production of thyroid hormones by the thyroid gland. The most common cause of hypothyroidism worldwide is iodine deficiency,

\section{Corresponding author:}

Dr. Afshan Sharghi. Department of Community Medicine, Faculty of Medicine, Ardabil, Ardabil University of Medical Sciences, Iran. Tel: +98-45-33534741, Fax: +98-45-33538939, E-mail: a.shrghi@arums.ac.ir

Received: October 15, 2019, Accepted: January 14, 2020, Published: March 2020

iThenticate screening: January 13, 2020, English editing: February 18, 2020, Quality control: March 03, 2020

This article has been reviewed / commented by three experts

Ethics approval: Ardabil University of Medical Sciences ethical committee (Ref.: IR.ARUMS.REC.1397.041).

(C) 2020 The Authors. This is an open access article under the terms of the Creative Commons Attribution-NonCommercialNoDerivs License, which permits use and distribution in any medium, provided the original work is properly cited, the use is non-commercial and no modifications or adaptations are made. 
and in places with sufficient iodine, other causes such as autoimmune diseases and iatrogenic are involved in the development of hypothyroidism (5). According to World Health Organization (WHO), about two million people have iodine poverty worldwide. Iodine deficiency is common in many mountainous regions as well as Central Africa, North Asia, and the interior region of South America. In areas with partial iodine deficiency, there was an increase in goiter prevalence and in areas with severe iodine deficiency there was an increase in the prevalence of hypothyroidism and cretinism or mental and developmental retardation. Children with cretinism are usually born in regions with iodine deficiency and mothers with iodine deficiency and thyroid hormone deficiency who are not treated with iodine or thyroid hormone. Adding iodine to salt, bread and other foods significantly reduces the incidence of cretinism (5). Over the past decades, many efforts have been made in developing - and underdeveloped countries to prevent and treat neurological disorders and mental retardation caused by hypothyroidism $(6,7)$. One way is to diagnose congenital hypothyroidism by routine neonatal screening in the first month of birth by measuring the levels of the thyroid hormones such as TSH and levothyroxine (T4). Up until 1970, before the emergence of the screening system, more than one-third of children with hypothyroidism had not been diagnosed at the appropriate time required and had severe mental and neurological disorders in the years following infancy. There is no cure and prevention at this stage of the disease, so, delay in diagnosis and treatment of hypothyroidism for 5 to 6 months reduces the level of intelligence to less than 70 (8-10). Therefore, early detection and treatment of hypothyroidism using T4 and determining its appropriate dose could prevent mental retardation in children with congenital Hypothyroidism (11).

Furthermore, due to greater prevalence of congenital hypothyroidism in Iran compared with that of Europe and South America (1 per 1000 in Iran vs. 1 per 3000 in Europe vs. 1 per 5000 in South America) and also due to the importance of the developmental status of children, especially in children with congenital hypothyroidism, in addition to the lack of study of this topic in Iran, particularly in Ardabil, the purpose of this study was to investigate the developmental status of 3 to 5-year-old children with congenital hypothyroidism treated with levothyroxine in Ardabil city.

\section{Material and Methods}

\section{1. Study design}

This is a descriptive cross-sectional study carried out on 78 children aged 3 to 5 years with permanent and transient congenital hypothyroidism who referred to Ardabil city Health Centers and were treated with levothyroxine during 2013-2018 in Ardabil, Iran. Exclusion criteria included anomalies affecting developmental function or symptoms of anomaly syndrome.

\subsection{Method of Data collection and ASQ measurement}

Data were collected by a checklist containing clinical and demographic information of patients such as age, gender, place of residence, parental relationship, parental education level, head circumference, birth weight and height, maternal age at delivery, time of diagnosis, disease and treatment initiation, number of referrals to doctor and results of follow-up. Ages and Stages Questionnaire (ASQ) assessed the developmental status of children by age and the questionnaire consisted of 30 questions with a score of 0-10 on the basis of five dimensions including communication, gross and delicate motions, and individual-social and problem solving which was used to assess 3 to 5-year-old children's developmental status. A "Yes" answer received a score of 10, a "Sometimes" answer received a score of 5 and a "No" answer received a score of zero. Its total score was compared with the standard score, and children based on ASQ final scores were divided into two impaired and normal status groups (12). Standardization and validation of the ASQ developmental disorders screening tool was determined and approved in a study by Sajedi et al. in Tehran, by evaluating children of Tehran city 913).

\subsection{Statistical analysis}

Data were analyzed by descriptive statistics, t-test and Chi-square using IBM $\odot$ SPSS $\odot$ Statistics version 21 (IBM $\odot$ Corp., Armonk, NY, USA). The significant level was set at 0.05 .

\subsection{Ethical approve}

The results of this study was approved by Ardabil University of Medical Sciences ethical committee and registered by code IR.ARUMS.REC.1397.041. 


\section{Results}

Of all studied children, $56.4 \%$ were male and the rest female. There were $71.8 \%$ from urban areas and the rest from rural areas. Based on ASQ results, $41 \%$ of children had impaired ASQ and of those $84.4 \%$ had permanent congenital hypothyroidism (Table 1). In all, $65.6 \%$ of children with impaired ASQ were boys, $62.5 \%$ from urban areas, $25 \%$ had familial history all of which, was not statistically significant (Table 1). There was no statistically significant difference between healthy and impaired children in terms of height, weight and head circumference and maternal age (Table 2). There was no significant difference between the number of tests performed and the mean of referrals to doctors in two ASQ groups in all ages and at all times (Table 3). The average of TSH in the newborns with impaired and healthy ASQ results had no significant difference at all times (Table 4). The results showed that there was no significant relationship between the developmental status of children and the age at diagnosis and treatment time (Table 5). There was significant difference between the dose of levothyroxine and ASQ results (Table 6).

Table 1. The Developmental status of children by type of congenital hypothyroidism, demographic data and familial history of disease

\begin{tabular}{|c|c|c|c|c|c|c|}
\hline \multirow[t]{3}{*}{ Variables } & & \multicolumn{4}{|c|}{ ASQ results } & \multirow[t]{3}{*}{$p$-value } \\
\hline & & \multicolumn{2}{|c|}{ Impaired } & \multicolumn{2}{|c|}{ Normal } & \\
\hline & & $\mathrm{n}$ & $\%$ & $\mathrm{n}$ & $\%$ & \\
\hline \multirow[t]{3}{*}{ Type of Congenital hypothyroidism } & Temporal & 5 & 15.6 & 6 & 13 & \multirow[t]{3}{*}{0.74} \\
\hline & Permanent & 27 & 84.4 & 40 & 87 & \\
\hline & Total & 32 & 41 & 46 & 59 & \\
\hline \multirow[t]{2}{*}{ Gender } & Girl & 11 & 34.4 & 23 & 50 & \multirow[t]{2}{*}{0.17} \\
\hline & Boy & 21 & 65.6 & 23 & 50 & \\
\hline \multirow[t]{2}{*}{ Residence place } & Urban & 20 & 62.5 & 36 & 78.3 & \multirow[t]{2}{*}{0.2} \\
\hline & Rural & 12 & 37.5 & 10 & 21.7 & \\
\hline \multirow{2}{*}{$\begin{array}{l}\text { Familial } \\
\text { history }\end{array}$} & yes & 8 & 25 & 15 & 32.6 & \multirow[t]{2}{*}{0.32} \\
\hline & no & 24 & 75 & 31 & 67.4 & \\
\hline \multirow{3}{*}{$\begin{array}{l}\text { Mother education } \\
\text { level }\end{array}$} & Under diploma & 10 & 31.2 & 10 & 21.7 & \multirow[t]{3}{*}{0.5} \\
\hline & Diploma & 16 & 50 & 23 & 50 & \\
\hline & Graduate & 6 & 18.7 & 13 & 28.3 & \\
\hline \multirow[t]{3}{*}{ Father education level } & Under diploma & 4 & 12.5 & 5 & 10.9 & \multirow[t]{3}{*}{0.6} \\
\hline & Diploma & 18 & 56.3 & 21 & 45.6 & \\
\hline & Graduate & 10 & 31.2 & 20 & 43.5 & \\
\hline
\end{tabular}

Table 2. Relation between ASQ with height, Weight, Head round in birth time and age of mother

\begin{tabular}{|c|c|c|c|}
\hline Variables & ASQ results & Mean \pm SD & p-value \\
\hline \multirow[t]{3}{*}{ Height $(\mathrm{cm})$} & Impaired & $49.1 \pm 3.4$ & \multirow[t]{3}{*}{0.23} \\
\hline & Normal & $94.2 \pm 2.07$ & \\
\hline & Total & $94.85 \pm 2.7$ & \\
\hline \multirow[t]{3}{*}{ Weight (gm) } & Impaired & $3076.6 \pm 756$ & \multirow[t]{3}{*}{0.35} \\
\hline & Normal & $3223.9 \pm 560$ & \\
\hline & Total & $3163.5 \pm 640$ & \\
\hline \multirow[t]{3}{*}{ Head round $(\mathrm{cm})$} & Impaired & $36 \pm 2.5$ & \multirow[t]{3}{*}{0.89} \\
\hline & Normal & $35.9 \pm 1.6$ & \\
\hline & Total & $35.9 \pm 13$ & \\
\hline \multirow[t]{3}{*}{ Mother age (years) } & Impaired & $26.5 \pm 5$ & \multirow[t]{3}{*}{0.37} \\
\hline & Normal & $27.4 \pm 3.8$ & \\
\hline & Total & $27 \pm 4.3$ & \\
\hline
\end{tabular}


Table 3. The Developmental status of children by number of trials and number of referral to physician

\begin{tabular}{|c|c|c|c|c|c|c|c|c|}
\hline $\begin{array}{l}\text { Age of } \\
\text { infant }\end{array}$ & $\begin{array}{l}\text { Time of } \\
\text { referral }\end{array}$ & $\begin{array}{l}\text { ASQ } \\
\text { results }\end{array}$ & $\begin{array}{l}\text { Number of } \\
\text { tests }\end{array}$ & $\%$ & $\begin{array}{l}\text { Mean of referral } \\
\text { number to doctor }\end{array}$ & $\begin{array}{l}\mathrm{p}- \\
\text { value }\end{array}$ & $\begin{array}{l}\text { Mean number } \\
\text { of trials }\end{array}$ & $\begin{array}{l}\mathrm{p}- \\
\text { value }\end{array}$ \\
\hline \multirow{6}{*}{$\begin{array}{l}\text { Three } \\
\text { years old }\end{array}$} & \multirow[t]{2}{*}{ First year } & Impaired & 11 & 27.5 & 4.63 & \multirow[t]{2}{*}{0.96} & 4.64 & \multirow[t]{2}{*}{0.86} \\
\hline & & Normal & 29 & 72.5 & 4.65 & & 4.58 & \\
\hline & \multirow{2}{*}{$\begin{array}{l}\text { Second } \\
\text { year }\end{array}$} & Impaired & 11 & 27.5 & 3.90 & \multirow[t]{2}{*}{0.04} & 3.64 & \multirow[t]{2}{*}{0.07} \\
\hline & & Normal & 29 & 72.5 & 3.38 & & 3.24 & \\
\hline & \multirow[t]{2}{*}{ Third year } & Impaired & 11 & 27.5 & 3.45 & \multirow[t]{2}{*}{0.48} & 3.08 & \multirow[t]{2}{*}{0.75} \\
\hline & & Normal & 29 & 72.5 & 3.24 & & 3.27 & \\
\hline \multirow{8}{*}{$\begin{array}{l}\text { Four } \\
\text { years old }\end{array}$} & \multirow[t]{2}{*}{ First year } & Impaired & 10 & 47.6 & 4.37 & \multirow[t]{2}{*}{0.27} & 4.60 & \multirow[t]{2}{*}{0.9} \\
\hline & & Normal & 11 & 52.4 & 4.63 & & 4.64 & \\
\hline & \multirow{2}{*}{$\begin{array}{l}\text { Second } \\
\text { year }\end{array}$} & Impaired & 10 & 47.6 & 3.56 & \multirow[t]{2}{*}{0.37} & 3.20 & \multirow[t]{2}{*}{0.6} \\
\hline & & Normal & 11 & 52.4 & 3.39 & & 3.36 & \\
\hline & \multirow[t]{2}{*}{ Third year } & Impaired & 10 & 47.6 & 3.06 & \multirow[t]{2}{*}{0.99} & 3.20 & \multirow[t]{2}{*}{0.6} \\
\hline & & Normal & 11 & 52.4 & 3.06 & & 3.36 & \\
\hline & \multirow{2}{*}{$\begin{array}{l}\text { Fourth } \\
\text { year }\end{array}$} & Impaired & 10 & 47.6 & 2.43 & \multirow[t]{2}{*}{0.18} & 2.30 & \multirow[t]{2}{*}{0.36} \\
\hline & & Normal & 11 & 52.4 & 2.70 & & 2.54 & \\
\hline \multirow{10}{*}{$\begin{array}{l}\text { Five } \\
\text { years old }\end{array}$} & \multirow[t]{2}{*}{ First year } & Impaired & 9 & 60 & 3.77 & \multirow[t]{2}{*}{0.12} & 3.78 & \multirow[t]{2}{*}{0.11} \\
\hline & & Normal & 6 & 40 & 4.67 & & 4.66 & \\
\hline & \multirow{2}{*}{$\begin{array}{l}\text { Second } \\
\text { year }\end{array}$} & Impaired & 9 & 60 & 2.89 & \multirow[t]{2}{*}{0.24} & 2.89 & \multirow[t]{2}{*}{0.35} \\
\hline & & Normal & 6 & 40 & 3.34 & & 3.34 & \\
\hline & \multirow{2}{*}{ Third year } & Impaired & 9 & 60 & 2.56 & \multirow[t]{2}{*}{0.63} & 2.89 & 0.64 \\
\hline & & Normal & 6 & 40 & 2.34 & & 2.67 & \\
\hline & Fourth & Impaired & 9 & 60 & 2.45 & 0.08 & 2.23 & 0.06 \\
\hline & year & Normal & 6 & 40 & 3.00 & & 2.83 & \\
\hline & Fifth year & Impaired & 9 & 60 & 1.89 & 0.34 & 2.12 & 0.78 \\
\hline & & Normal & 6 & 40 & 2.17 & & 2.17 & \\
\hline
\end{tabular}

Table 4. The developmental status of children by mean of TSH in first year of treatment

\begin{tabular}{|l|l|l|l|l|l|}
\hline Time of test & ASQ results & $\mathrm{n}$ & $\%$ & Mean Rank & p-value \\
\hline Birth time & Impaired & 32 & 41 & 41.6 & 0.48 \\
\cline { 2 - 6 } & Normal & 46 & 59 & 38 & \\
\hline \multirow{2}{*}{ After three years } & Impaired & 11 & 27.5 & 23 & \multirow{2}{*}{0.42} \\
\cline { 2 - 6 } & Normal & 29 & 72.5 & 19.55 & \\
\hline \multirow{2}{*}{ After four year } & Impaired & 10 & 47.6 & 11.85 & \multirow{2}{*}{0.56} \\
\cline { 2 - 5 } & Normal & 11 & 52.4 & 10.23 & \\
\hline \multirow{2}{*}{ After five year } & Impaired & 9 & 60 & 8.89 & \multirow{2}{*}{0.39} \\
\cline { 2 - 5 } & Normal & 6 & 40 & 6.67 & \\
\hline
\end{tabular}

Table 5. Relation between developmental status with age at the diagnosis and after treatment

\begin{tabular}{|l|r|r|r|}
\hline \multirow{2}{*}{ Variables } & \multicolumn{2}{|c|}{ ASQ results } & \multirow{2}{*}{ p-value } \\
\cline { 2 - 3 } & Impaired & Normal & \\
\hline Age in diagnosis time (day) & 50.2 & 32.1 & 0.001 \\
\hline Age in treatment time (day) & 48.5 & 33.3 & 0.003 \\
\hline
\end{tabular}

Table 6. The developmental status of children by dose of Levothyroxine $(\mathrm{mg} / \mathrm{kg})$

\begin{tabular}{|l|l|l|l|l|l|}
\hline \multirow{3}{*}{ Levothyroxine } & \multicolumn{3}{|l|}{ ASQ results } & \multirow{2}{*}{ p-value } \\
\cline { 2 - 5 } & Impaired & \multicolumn{2}{|c|}{ Normal } & \multirow{4}{*}{} \\
\cline { 2 - 5 } & $\mathrm{n}$ & $\%$ & $\mathrm{n}$ & $\%$ & \\
\hline$<8$ & 22 & 28.2 & 19 & 24.5 & \multirow{2}{*}{0.02} \\
\hline$\geq 8$ & 10 & 12.8 & 27 & 34.5 & \\
\hline
\end{tabular}




\section{Discussion}

Congenital hypothyroidism is the most common treatable congenital disease, which can lead to mental or growth retardation and delay in infant Neuromotor development in the absence of timely diagnosis, or incomplete treatment. In this study, $41 \%$ and $59 \%$ of patients had impaired and normal ASQ results respectively. According to the study by LaFranchi et al., the ASQ test is more sensitive and specific than other tests for measuring developmental disorders, and was similar to our study results (14). Marks et al., in their study, observed that ASQ testing more closely examines the developmental status of 3 to 6 months children (12). In line with the present study, the study by Namakin et al., showed that the average score of ASQ based on developmental indices in children with congenital hypothyroidism was significantly lower than in healthy children (13). In the Mozaffari et al. study, $17.2 \%$ of children had no ASQ quorum score and the relative risk of neuro developmental disorders was 1.4 which, compared with the results of the present study, had a lower percentage of neuro developmental disorder and the reason for this may be the small sample size of the present study (14).

Frezzato et al. in their study, showed that delayed major and delicate movements between the two healthy and levothyroxine treated groups was often associated with speech delay (15). The study by Gejao, Komur et al., in line with the results of the present study, indicated a weakness in speech and communication skills in these children $(16,17)$. Soliman et al. in a study did not find any developmental disorders among children treated with levothyroxine, which was not in line our findings (18)

In this study, a statistically significant relationship was found between ASQ test outcome and age at diagnosis and age at treatment initiation. Consistent with the results of this study, Pniewska-Siark et al., in their study, showed that early diagnosis and treatment of hypothyroidism had a good prognosis in the first two weeks of birth (19). In the study of Arenz et al., cognitive development, BMI and motive skills evaluated in children with persistent congenital hypothyroidism were treated with levothyroxine at 4 to 15 days postpartum during preschool, and results showed similarities to those of other children (20). A study by Aijaz et al. showed that, earlier treatment with levothyroxine evolved neurological and brain development, which was similar to our study results (21). A study by Boileau et al. found that, the Intelligence Quotient (IQ) of children who were treated before 21 days of age was higher than those treated after this age (22). In this study, there was no statistically significant relationship between ASQ test results and initial dose of levothyroxine. Selva et al., in their study, found that the initiation of high dose levothyroxine treatment in the first two weeks of birth was not significantly different from the low dose, but showed a significant difference in intelligence (5). In the study of Boileau et al., no significant difference was found between IQ and Levothyroxine doses, which was not in line with the present study (22). In this study, no correlation was found between children's developmental indices with baseline Thyroid-stimulating Hormone (TSH) and TSH average in the first year. In a LaFranchi et al.'s study it was found that there was no significant difference between different doses of levothyroxine and its combination with triyodotironina on children's developmental status and motive skills (3). The findings of a Baysal et al.'s study showed that factors such as gender, socioeconomic status of the family, birth weight and duration of serum TSH normalization after treatment had no significant effect on the development of children (23). Similar to our study results, Razavi et al., in their study, showed that early diagnosis and treatment along with initial levothyroxine dose were most important factors of ASQ scores of children with $\mathrm{CH}$. Higher dose of the levothyroxine is required at onset (24).

\section{Study limitations}

There are some limitations for this study such as lack of access to all the infants (by phone call or by interview), small sample size of study for better conclusion and discussion and also determining the impact of nutrition.

\section{Conclusions}

Based on the findings of this study, it can be concluded that neonatal screening is one of the most successful health programs in Iran, and early detection and initiation of hypothyroidism in neonates, could reduce the developmental abnormalities in these children. Given the potential impact of congenital hypothyroidism in later years, especially in their learning, it is necessary to follow this study up to school-age in these children.

\section{Acknowledgments:}

We want to thank all parents of children who participated in this study and also all Imam-Khomeini hospital staff for their help in conducting this study. 


\section{Conflict of Interest:}

There is no conflict of interest to be declared.

\section{Authors' contributions:}

All authors contributed to this project and article equally. All authors read and approved the final manuscript.

\section{References:}

1) Morreale dE, Obregon MJ, Escobar D R. Role of thyroid hormone during early brain development. Eur J Endocrinol. 2004;151: 25-37. DOI: 10.1530/eje.0.151u025. PMid: 15554884

2) Bernal J. Thyroid hormones and brain development. Vitamin Horms 2005; 71: 95-1. DOI: 10.1016/S00836729(05)71004-9.

3) LaFranchi S. Congenital hypothyroidism: etiologies d and management. Thyroid.1999; 9(7):735-40. PMID: 10447022 DOI: 10.1089/thy.1999.9.735.

4) Hashemipour M, Hovsepian S, Kelishadi R, Iranpour R, Hadian R, Haghighi S, et al.Permanent and transient congenital hypothyroidism in Isfahan-iran. J med screen 2009;16(1):11-16. doi: 10.1258/jms.2009.008090. PMid: 19349525

5) Selva K, Harper A, Downs A, Blasco P, Lafranchi S. Neurodevelopmental outcomes in congenital hypothyroidism: comparison of initial T4 dose and time to reach target T4 and TSH. The Journal of pediatrics. 2005; 147(6):775-80. PMID: 16356430 DOI: 10.1016/j.jpeds.2005.07.024.

6) Bargagna S, Canepa G, Costagli C, Dinetti D, Marcheschi M, Millepiedi S, et al. Neuropsychological follow- up in early- treatment congenital hypothyroidism: a problem- oriented approach. Thyroid 2000; 10 (3): 243-9. PMID: 10779139 DOI: 10.1089/thy.2000.10.243.

7) Bongers- Schokking J, de Muinck Keizer- Schrama S. Influence of timing and dose of thyroid hormone replacement on mental, psychomotor, and behavioral development in children with congenital hypothyroidism. J Pedistr 2005; 147(6): 768-7. https://doi.org/10.1016/j.jpeds.2005.09.031 PMid: 16356429

8) Dussault JH. The anecdotal history of screening for congenital hypothyroidism. J Clin Endocrinol Metab 1999; 84(12): 4332-4. PMID: 10599683 DOI: 10.1210/jcem.84.12.6221.

9) Dussault JH, Coulombe P, Laberge C, Letarte J, Guyda H, khoury K. Preliminary report a mass screening program for neonatal hypothyroidism. J Pediatr 1995; 85(5): 670-4. PMID: 1133648 DOI: 10.1016/s00223476(75)80349-0

10) Fisher D, Dussault J, Foley $T$, Klein A, Lafranchi S, Larsen PR, et al. Screening for congenital hypothyroidism: results of screening one million North American infants. J Pediatr 1995; 94(5): 700-5. https://doi.org/10.1016/S0022-3476(79)80133-X

11) Rovet J, Daneman D. Congenital hypothyroidism: a review of current diagnostic and treatment practices in relation to neuropsychologic outcome. Paediatr Drugs 2003; 5(3): 141-9. PMID: 12608879 DOI: 10.2165/00128072-200305030-00001.

12) Marks K, Hix-Small H. Impact of implementing ASQ developmental screening in a pediatric practice. Peace Health Medical Group Eugene. 97401; 31-34. Available from: https://nashp.org/wpcontent/uploads/sites/default/files/abcd/abcd.or.powerpoint.asq.pdf.

13) Namakin K, Sedighi E, Sharifzadeh G, Zardast M. Prevalence of congenital hypothyroidism In South Khorasan province (2006-2010). J Birjand Univ Med Sci. 2012; 19 (2):191-199.

14) Mozafari kermani R, Ahmadi A, Sedighi J, Tavoussi M, Haeri Mehrizi A, Rostami R, et al . Evaluation of the Incidence of Neurodevelopmental Disorders in Children Aged 1 to 3 Years with Congenital Hypothyroidism Treated with Levothyroxine. Payesh 2018; 17 (4): 399-407.

15) Frezzato R, Santos D, Goto M, Ouro M, Santos C. Fine motor skills and expressive language: a study with children with congenital hypothyoidism. Codas. 2017; 29:1. DOI: 10.1590/2317-1782/20172016064. PMid: 28300959

16) Gejao MG, Lamônica DA. Development skills in children with congenital hypothyroidism: focus on communication. Pro Fono 2008; 20(1): 25-30. PMid: 18408860

17) Komur M, Ozen S, Okuyaz C, Makharoblidze K, Erdogan S. Neurodevelopment evaluation in children with congenital hypothyroidism by Bayley-III. Brain Dev 2013; 35(5): 392-730. https://doi.org/10.1016/j.braindev.2012.07.003 PMid: 22858380

18) Soliman H, Abdel Hady A, Abdel Hamid A, Mahmoud H. Language profile in congenital hypothyroid children receiving replacement therapy.Folia Phoniatr Logop 2016;68:231. https://doi.org/10.1159/000448744 PMid: 27584159 
19) Pniewska-Siark B, Jeziorowska A, Bobeff I, Lewiski A. Analysis of physical and mental development of children with aplasia, hypoplasia and ectopy of the thyroid gland. Endocrine Regulations 2006; 40: 7-14.

20) Arenz S, Nennstiel - Ratzel U, Wildner M, Dörr H, Von Kries R. Intellectual outcome, motor skills and BMI of children with congenital hypothyroidism: a population - based study. Acta paediatrica 2008; 97(4):447-50. https://doi.org/10.1111/j.1651-2227.2008.00702.x PMid: 18331367

21) Aijaz N, Flaherty E, Preston T, Bracken S, Lane A, Wilson T. Neurocognitive function in children with compensated hypothyroidism: lack of short term effects on or off thyroxin. BMC Endocr Disord 2006; 6: 2. DOI: 10.1186/1472-6823-6-2. PMid: 16549027 PMCid: PMC1435757

22) Boileau P, Rives S, Toublanc J. Earlier onset of treatment or increment in LT4 dose in screened congenital hypothyroidism: Which as the more important factor for IQ at 7 years? Horm Res 2004; 61:228-33. https://doi.org/10.1159/000076597 PMid: 15115051

23) Baysal B, Baysal B, Genel F, Erdur B. Neurodevelopmental outcome of children with congenital hypothyroidism diagnosed in a national screening program in Turkey. Indian Pediatrics 2017; 54:381-4. https://doi.org/10.1007/s13312-017-1111-5 PMid: 28368265

24) Razavi Z, Dalili S, Sabzehei MK, et al. Developmental Screening of Children with Congenital Hypothyroidism Using Ages and Stages Questionnaires Test. Iran J Child Neurol. 2019;13(2):145-154. 